\title{
EVALUATING THE IMPACT OF ENTERTAINMENT PROGRAMS OFFERED IN THE FLOATING HOTEL ON GUEST SATISFACTION IN LUXOR
}

\section{$\overline{\overline{20}}$ \\ HANY ATEF KOUZMAL \\ HIGHER INSTITUTE FOR TOURISM AND HOTELS, LUXOR (EGOTH)}

\begin{abstract}
This study aims to evaluating the impact of entertainment programs offered in the floating hotel on guest satisfaction. The importance of this study lies in dealing with entertainment, which is considered as one of the effective factors that increase guest satisfaction. So this research can provide a description of entertainment and its importance in increasing guest satisfaction. Research respondents divided into two target groups. First: the employees. Second: the floating hotels guests. The study was conducted in September to December 2019 in Luxor, on a sample of 21 floating hotels. The questionnaires are closed-ended (with offered answers: Likart scale). The method of data collection was self-completion questionnaire, returned by e-mail, online Google drive and personally collected by the researcher. The collected questionnaires were encrypted and statistically analyzed using SPSS 20.
\end{abstract}

Hypothesis testing has been done using Pearson correlation coefficient. Preliminary analyses were performed to ensure no violation of Hypothesis of normality and linearity. The results assured that there is a statistically significant effect on the factors of guest satisfaction on the performance level of the entertainment programs in Luxor floating hotels.

Findings- The respondents are aware of the advantages of the different parts that measure entertainment services in floating hotels in Luxor and ranking them as follows: The impact and the importance of the role of entertainment services were the first efficiency; Assessment of entertainment services level was in the second rank level; evaluating entertainment services was in the third rank level.

Recommendation - The more variety of entertainment programs should be offered by entertainment team; the extra care regarding protective fees for security and safety to prevent problems that may be caused by entertainment services.

KEYWORDS: Guest Satisfaction, Recreational Activities, Entertainment Programs, Floating Hotel in Luxor. 


\section{INTRODUCTION}

Entertainment is a pleasure, recreation and revitalization. Entertainment is an activity we do in leisure. The need for recreational activities is an essential element in psychology and human biology. Entertainment is an important part of human life. The tourism sector has said that it is entertainment that attracts many visitors. Nowadays entertainment is an urgent requirement in the busy daily life of work, technological progress and times demands, leading to much psychological stress on the family and society. There are many benefits of entertainment for the health; accordingly, treatment using entertainment has evolved such as the use of modern floating hotels in the treatment of guests from their boredom (Petler et al., 2016; Antchak, 2017). This study wishes to evaluate the entertainment programs offered in the Luxor floating hotels and its impact on guest satisfaction.

The aim of the study is to evaluate the level of performance in the entertainment programs, and how far does it affect the satisfaction of guests towards floating hotels in Luxor and what is the impact of guest satisfaction.

The objective of this study is to measure guest satisfaction by assessing the performance in the entertainment of the floating hotels in Luxor and determining the relationship between guest satisfaction policies and the performance of the entertainment programs.

\section{PROBLEM AND QUESTIONS OF THE STUDY}

Floating hotels activity depends mainly on persons in achieving its objectives and achieving guest satisfaction; entertainment programs offered in the floating hotels have an impact on guest satisfaction; and employees in the entertainment department have a steady role in the process of guest satisfaction. This study will shed light on the reality of the entertainment; based on the opinions of experts in the field of floating hotels, it can be said that there are a number of indicators. It is deduced from the existence of some shortcomings of the entertainment, which affected the process of guest satisfaction. the study chooses the entertainment programs as a very important factor in the customer satisfaction during his trip and the Floating hotels are very important to the tourism and hotels industry that's why the study choose the Luxor floating hotels as a very important sector of the Egyptian accommodation establishments.

The problem of the study lies in answering the following questions:

1. How guests are satisfied with the service provided by the entertainment team of the floating hotels in Luxor? 
2. What is the level of performance of the entertainment team in floating hotels in Luxor?

3. Are there differences of statistical significance in the level of performance impact on the process of satisfaction of guests due to the variable (age - nationality - academic qualification)

4. Are there any differences in the level of offers presented in the entertainment team? How far do they affect guests?

\section{AIM AND OBJECTIVES OF THE STUDY}

The study will shed light on the reality of the entertainment; based on the opinions of experts in the field of floating hotels, it can be said that there are a number of indicators. It is deduced from the existence of some shortcomings of the entertainment team, which affected the process of guest satisfaction.

\section{THE IMPORTANCE OF THE STUDY}

The importance of this study lies in dealing with entertainment, which is considered as one of the effective factors that increase guest satisfaction. So this research can provide a description of entertainment and its importance in increasing guest satisfaction.

1. Academic level: The library of the floating hotel lacks the contributions of researchers in specialized and deep studies in the evaluation of the performance of the entertainment team and its relation to the level of guest satisfaction and thus improving the performance of floating hotel services in floating hotels sample study.

2. Practical application level: This study aims at identifying the performance of the entertainment program and its impact on guest satisfaction, which leads to the identification of the most important problems facing improvement, development and raise the level of efficiency of the performance and how to achieve guest satisfaction. Perhaps this study contributes to provide a number of recommendations and proposals to activate the satisfaction of guests and then raise the performance levels of entertainment in order to perform their tasks efficiently and effectively.

\section{LITERATURE REVIEW}

\section{GUEST SATISFACTION DEFINITION}

"Satisfaction is a person's feeling of pleasure or disappointment resulting from comparing a product's perceived performance (or outcome) in relation to his or her expectations" (Philip and Armstrong, 2014). Generally, "guest satisfaction is the feeling of guest who has experienced the hotel service and then the judgments of satisfaction or dissatisfaction 
are made "(Tong, 2015). Chen and Sun, 2019 identify satisfaction as" a comparison between guests' expectations and feelings before and after the experiment. If the expected value after tourism is greater than the satisfaction value before tourism, guests are satisfied". According to Petler et al., 2016 entertainment is "a type of leisure activity that an individual chooses to pursue self-motivated and which results from his acquisition of physical, moral, cognitive and social values". John, 2011 explained that satisfaction is "an attitude that reflects what a person feels. Most of the hotels these days fail to recognize that involving their employees in contests is a fundamental component in order to have a guest satisfaction and growing business".

Auh and Johnson, 2005 clarified that the satisfaction concept may be understood as the guest expectations or the tendency to repurchase the hotels services. Also lewin, 2009 asserted that the benefits of guest satisfaction include revenues increase; reduce guest-related transaction costs and reductions in price elasticity among repeat guests. Guest does not usually make purchases without thinking carefully about leisure requirements (Ganiyu et al., 2012). Guest satisfaction can influence floating hotel brand name and increases profit (Davoud and Hamed, 2012). Chen and Sun, 2019 wrote that a higher satisfaction leads to greater levels of loyalty and increasing sales. So Antchak, 2017 pointed out that hotels success is depending on the understanding the relation among entertainment, recreation and tourism. Akhoondnejad, 2018 advised the floating hotels managers to take into consideration simultaneously the needs and expectations of guest segments to increase satisfaction and loyalty. There is no doubt that every single enterprise wants to keep their guests, not only to make their guests satisfied, but also make them be retention (Tong, 2015).

Hotels industry has involved in the increasing competition for customer satisfaction. Therefore, floating hotel needs to understand with as much precision as possible what the guests want from the service. Previous empirical study found a strong positive relationship for customer satisfaction and customer retention (Syaqirah and Faizurrahman, 2014). To offer satisfactory experiences to consumers, recreation programs providers need to have a vision oriented to customer value, effective communication systems and greater cooperation and integration among recreation team and the guest (Marques et al., 2016).

\section{RECREATION AND ENTERTAINMENT DEFINITION}

Pratt et al., 2007 identifies recreation as practicing any activity in the spare time whether it is an individual or group activity and that it present pleasure without waiting for any reward. While John, 2011 showed that 
recreation is considered as an activity voluntarily undertaken, primarily for pleasure and satisfaction during leisure time. Timpe, 2017 also adopted the same point of view as he said that "recreation is activities and experiences usually carried on within leisure and usually chosen voluntarily for satisfaction, pleasure, or creative enrichment". Luo and Lam, 2017defined "Entertainment tourism as economic activities based on integrated services provided by the entertainment and tourism sectors, is a rising trend around the world" and pointed that the entertainment has been rising along with the destination in the last decade.

Al Hashemi et al., 2018 pointed out that "recreation or entertainment is an English word means renewal, creation and innovation and there are theories and interpretations of it as it outweighs the concept of play". Recreation and leisure are interpreted as an emotional reaction or a psychological state and a feeling felt by the individual before and during the workout of an activity, and during leisure time and that the individual driven by personal desire and is characterized by freedom of choice and its purpose in itself, "Entertainment is more than activity, activity is not an end in itself, the end is that change in the emotional and emotional state and the sense of joy and happiness" (Antchak, 2017).

Allen, 2013 stated that there is differentiated between entertainment and recreation that entertainment is an emotional state that afflicts the individual as a result of his sense of good presence in life and satisfaction, and that recreation is characterized by feelings related to mastery, achievement, recovery, acceptance, success, self-value, pleasure, positive reinforcement of the self-image, as well as It is a leisure-related and socially acceptable activity. Luo et al., 2016 gave examples of entertainment products saying that they come in many forms, such as talk shows, concerts, magic performance, gambling, and dance performance. Gambling, which is also an entertainment product, is a key determinant of economic growth in many countries.

\section{RECREATION AND ENTERTAINMENT IN TOURISM AND HOTEL}

Entertainment destinations and hotels are places where guest participate in entertainment activities. Philip and Armstrong, 2014 explained that guests have strong requirements for recreation, and entertainment. These requirements become wants when they are directed to specific objects that might satisfy the need. De Klerk, 2012 said that many guests depend on the entertainment sector of the tourism industry to give them a memorable and pleasurable holiday.

Hotels are the cordial and generous reception and entertainment for guests or strangers socially or commercially (Chang and Taylor, 2016). Heidbrink, 2019 explained that one of the most vital elements of the success of a traditional Antarctic cruise that advanced since the 1970s was 
an entertainment of lectures onboard of the ship that replaced the standard onboard entertainment program of a predictable cruise ship, all kinds of show-acts, musical presentations, cocktail parties, black-tie, white tie dinners.... etc. In addition, these experts served as guides during the zodiac cruises and the landings. The program was like the program of an adult education center than the entertainment program of a traditional cruise ship. All kinds of show-acts, musical performances, black-tie cocktail parties, white tie dinners etc. were small or non-existent compared to traditional, non-expedition cruise ships. Experts on subjects like glacial environment, geology, oceanography, glaciology and the history of the Regions joined the cruises and provided detailed information during the lectures.

Weiermair and Mathies, 2007 showed that Theme Parks and hotels aims to create an atmosphere of another place and time, and frequently concentrates on one main theme, around which architecture, landscaping, costumed personnel who are known as animators, and different facilities for entertainment, recreation, or physical activities. Shujat et al., 2011 advocated integrating recreational and entertainment activities in the hotel culture and it can be termed as an unconventional approach to keep the guest satisfied. For De Klerk, 2012 hotel entertainment is an important element of tourism package today, even though the concept is not well treated as an entity on its own, but it is a paramount part of the service sector which enables guests to have a lasting impression.

Allen, 2013 stated that recreation is an essential part of human life and finds many different forms which are shaped naturally by individual interests but also by the surrounding social construction. Recreational activities can be active or passive, outdoors or indoors, healthy or harmful, and useful for society or detrimental. Türk, et al., 2004 pointed out that recreation is an activity of leisure. Recreational activities are often done for enjoyment, amusement, or pleasure and are considered to be "fun". Outdoor recreation has been broadly defined to include: Just being outdoors; Creative activities; Health or relaxation; Utility journeys; Informal games and play; High adrenalin, non-competitive activities; Commercially run activities; Study of the natural environment; Educational activities and programmers; Conservation volunteering; Sustainable journeys to outdoor recreation.

According to Timpe, 2017 the goals of entertainment have basic functions for the human person, the most important of which is preparing for future life and achieving a balance among its various forces. Therefore, the countries have taken an interest in investing free time in the development of individuals from all sides. Adapt to him and combined). Shujat et al., 2011suggested Integrating recreational and entertainment activities in the 
hotel as culture can be termed as an unconventional approach to keep the guest satisfied

\section{ENTERTAINMENT AND SATISFACTION}

Shujat et al., 2011 showed that satisfaction with activities in leisure time is a positive feeling that the individual has as a result of being able to participate in entertainment activities to benefit their spare time using free choices. According to Timpe, 2017 general satisfaction consists of total satisfaction with the partial aspects among which the feelings of the individual are formed (satisfaction with pay - satisfaction with supervision - satisfaction with the type and content of the offered program and others) according to the weight and the relative importance of each type of feelings in its contribution to the degree of overall satisfaction and feelings, while satisfaction is a specific aspect of aspects of services, it is the outcome of the type and strength of individual needs that this particular aspect satisfies Lkhamtseden and Altanchimeg, (2017).

Most of the leisure has focused on entertainment and gaming. Tong, 2015 clarified that in order to make guests be satisfied, they need to be satisfied with the recreation and entertainment services that they have experienced first. Hence, in order to make guests satisfied and accordingly to be loyal, the entertainment programs quality needs to be improved. Hence, analyzing the relationship between guest satisfaction and guest loyalty and improving them has played a very important role in competition with other hotels. Therefore, today, the competition is more likely to satisfy and win guests. So Rechner, 2010 stated that recreational and entertainment programs are other huge components of the hotels. In the same way Philip, 2014 advised Hotels manager to ask their guests what they are interested in, what recreation and entertainment activities they would like, what entertainment programs they would want, and how, when, and how often they would accept leisure from the hotel

While Moital1, 2019 showed that the failure is on the methodologies within national statistical services between entertainment, leisure and culture, Mkono and Holder, 2019 showed that future studies will also be beneficial for travel, recreation, entertainment, guest, and tourism studies, this means research frameworks that draw on other disciplines and areas of study: geography, human psychology, ecology, economics, and politics, among others.

\section{RESEARCH CONCEPTUAL FRAMEWORK}

Guest satisfaction and retention foundational processes based on the theoretical ambiguity surrounding the entertainment - informed guest satisfaction, develop an integrative framework incorporating these 
theoretical entities, thus taking a step toward their conceptual consolidation.

In the remainder of this section, discuss evaluating the impact of entertainment programs offered in Luxor floating hotels on guest satisfaction.

Syaqirah and Faizurrahman, 2014 pointed out that guest satisfaction and retention dimensions are expectation to repurchase; recommend to others; overall satisfaction

This section constructs a conceptual framework to explore the effect of entertainment programs on the guest satisfaction and retention. The framework comprises three parts, namely the entertainment programs; Satisfaction with other hotels services; and Guest satisfaction and retention as shown in Figure 1.

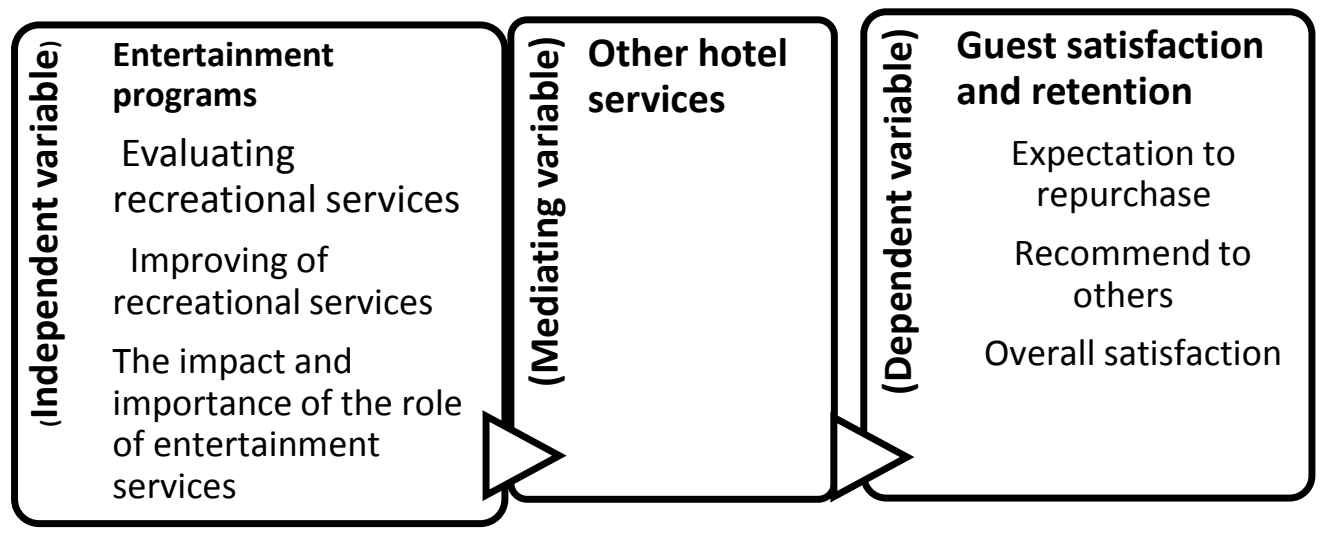

Figure 1: The research Conceptual Framework A

\section{HYPOTHESIS OF THE STUDY}

This study is based on the main hypothesis that:

$\checkmark$ H1: There is a statistically significant relationship between evaluating, Improving the level, and the role of entertainment services:

- H1A: There is statistically significant relationship between the evaluating entertainments services Vs Improving the level of entertainment services.

- H1B: There is statistically significant relationship between evaluating entertainment services Vs the impact of the role of entertainment services.

- H1C: There is statistically significant relationship between improving the level of entertainment services Vs the impact of the role of entertainment service.

$\checkmark$ H2: There is statistically significant impact of the entertainment programs on the guest satisfaction as shown in Figure 2. 


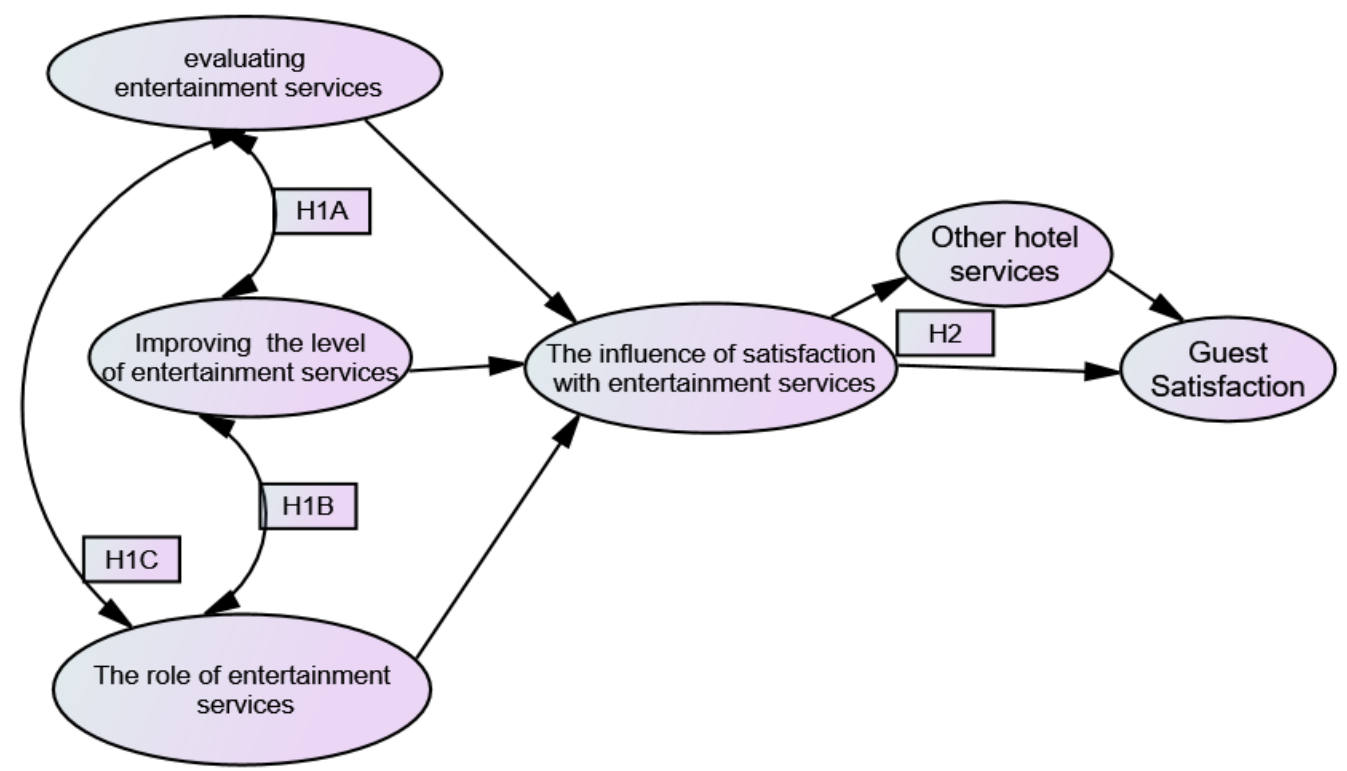

Figure 2: The Hypothesis of the study

\section{MeTHODOLOGY}

The research was conducted using two simple questionnaires adapted to two target groups. First: the employees such as (floating hotels managers, departments' managers and supervisors, and other employees). Second: the floating hotel guests. The survey was reviewed by academic lecturers from the higher institute of tourism and hotels in Luxor and from faculty of tourism and hotels Luxor University to review the questionnaires as well as to find out the on duty and ready to support floating hotels; all notes and suggestions have been taken in confederation. Pilot study was carried out by distributing 30 questionnaires for the floating hotels departments' managers and supervisors (animation manager, animation supervisor recreation manager, recreation supervisor, chief leader, food and beverage manager, rooms division manager) as well as 3o guest questionnaire in August 2019 and the study was conducted in September to December 2019 in Luxor, on a sample of 22 floating hotels. The questionnaires are closedended (with offered answers: Likart scale). The method of data collection was self-completion questionnaire, returned by e-mail and personally collected by the researchers. The collected questionnaires were encrypted and statistically analized using SPSS 20.

This paper focuses on the entertainment and its effect on guest satisfaction in floating hotels in Luxor that boarding from Luxor to Aswan and reverse. 


\section{THE SAMPLE POPULATION}

The floating hotels samples of this study were selected from the five star floating hotels in based of availability and support. According to the guide of the Egyptian Hotel Association (EHA), (2019) there are 200 floating hotels 5 star categories in Egypt but in this period in Luxor only about 64 floating hotel boarding and in operation. The study was conducted on a sample of 22 Luxor Floating hotels representing $11 \%$ of the total number of the total floating hotels and $34 \%$ of on boarding Luxor floating hotels. These numbers belong to the availability, boarding, and the cooperation of the floating hotels. The following table (1) shows the list of investigated floating hotels.

\section{Table (1) The Sample Population floating hotels 5 star category}

\begin{tabular}{|c|c|c|c|c|c|c|}
\hline \multicolumn{3}{|c|}{ The Sample Population floating hotels 5 star category } & \multicolumn{2}{|c|}{$\begin{array}{c}\text { Guests } \\
\text { questionnaire }\end{array}$} & \multicolumn{2}{|c|}{$\begin{array}{c}\text { employees } \\
\text { questionnaire }\end{array}$} \\
\hline No. & Floating hotel name & 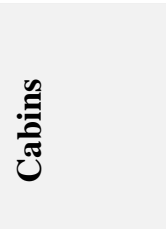 & 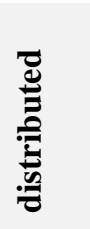 & $\underset{7}{\overparen{T}}$ & 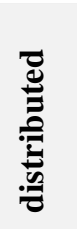 & 를 \\
\hline 1. & Nile Admiral & 85 Cabins & 40 & 37 & 20 & 18 \\
\hline 2. & Crown Jewel & 84 Cabins & 40 & 35 & 20 & 16 \\
\hline 3. & Crown Prince & 81 Cabins & 40 & 34 & 20 & 15 \\
\hline 4. & Miss World & 76 Cabins & 40 & 34 & 20 & 16 \\
\hline 5. & Altamira & 76 Cabins & 40 & 32 & 20 & 16 \\
\hline 6. & Alkahila & 76 Cabins & 40 & 31 & 20 & 15 \\
\hline 7. & Swiss Inn Radamis II Nile Cruise & 75 Cabins & 40 & 30 & 20 & 15 \\
\hline 8. & Beausoleil & 74 Cabins & 40 & 28 & 20 & 14 \\
\hline 9. & Emelio & 72 Cabins & 40 & 33 & 20 & 14 \\
\hline 10. & Princess Sarah & 66 Cabins & 40 & 33 & 15 & 13 \\
\hline 11. & MS Sunray Nile Cruise & 66 Cabins & 40 & 28 & 15 & 13 \\
\hline 12. & Concerto & 65 Cabins & 40 & 33 & 15 & 14 \\
\hline 13. & Farah & 62 Cabins & 40 & 30 & 15 & 13 \\
\hline 14. & Sone Stasun Goddess & 62 Cabins & 40 & 30 & 15 & 14 \\
\hline 15. & The Oberoi Philae Nile Cruiser & 58 Cabins & 30 & 27 & 15 & 13 \\
\hline 16. & Sone Stast. George 1 & 57 Cabins & 30 & 27 & 15 & 13 \\
\hline 17. & KINGMINA & 56 Cabins & 30 & 25 & 15 & 13 \\
\hline 18. & Amaraante Isis & 55Cabins & 30 & 26 & 10 & 9 \\
\hline 19. & Amarco I & 53 Cabins & 30 & 24 & 10 & 9 \\
\hline 20. & Sone Stamoon Goddess & 53 Cabins & 30 & 24 & 10 & 9 \\
\hline
\end{tabular}




\begin{tabular}{|c|c|c|c|c|c|c|}
\hline 21. & Darakum & 52 Cabins & 30 & 25 & 10 & 9 \\
\hline 22. & QUEEN ISIS & 51 Cabins & 30 & 22 & 10 & 8 \\
\hline & & & 800 & 648 & 340 & 289 \\
\hline
\end{tabular}

\section{Adapted From: Egyptian Hotel Association (Eha), (2019).}

\section{DATA COLLECTION}

\section{EMPLOYEES AND GUEST QUESTIONNAIRES}

Regarding the data collection, the study was conducted in September to December 2019 in Luxor, on a sample of 22 floating hotels. The total number of questionnaire forms through employees is 350 questionnaires that distributed in accordance to floating hotel capacity (20 employees questionnaire form to 9 floating hotels which have more than 70 cabin each; and 15 employees questionnaire form to 8 floating hotels which have from 56 to 70 cabin; and 10 employees questionnaire form to 5 floating hotels which have more than 56 cabin). Questionnaires were distributed to employees working in different jobs such as animation manager "chief animation", animation supervisor recreation manager, recreation supervisor, chief leader, recreation team members and pool worker, health club team; As well as front office manager, supervisors and receptionist; moreover, food and beverage manager, assistant, headwaiters, captain. The study chooses the respondents within different departments in investigated place. Only 289 questionnaires were valid and ready to be analysed by percentage of $82.6 \%$. Concerning the respondents' departments, the study focus on the entertainment team and guest contact employees such as frooms divisions and food and beverages division.

Moreover, the total number of questionnaires forms distributed to guests was 800 questionnaires. Distributing 40 guest questionnaire form to 14 floating hotels which have more than 60 cabin each, and 30 guest questionnaire form to 8 floating hotels which have less than 60 cabin. Only 648 guest questionnaires were correctly received and ready to be analized by percentage $81 \%$. It is an indicator that there is an increasing awareness of guests about the level of performance in the entertainment programs, and how far this level affected the satisfaction of guests to floating hotels in Luxor and what the impact of guest satisfaction is.

\section{RESULTS AND DISCUSSION}

\section{STUDY INSTRUMENT RELIABILITY}

Pallant, 2007; Hair et al., 2010 showed that for all scales, the Cranach Alpha reliability was computed and the tests showed that the reliability coefficients for all the instruments were above 0.7 , which indicates that the 
instrument is reliable for being used. Cronbach alpha for all survey instruments is shown in the following table 2 :

Table (2) Reliability statistics

\begin{tabular}{|l|c|c|c|}
\hline \multicolumn{1}{|c|}{ Questionnaire } & $\begin{array}{c}\text { Cronbach's } \\
\text { Alpha }\end{array}$ & No. of Items & $\begin{array}{c}\text { No. of Item } \\
\text { questionnaire }\end{array}$ \\
\hline $\begin{array}{l}\text { Employee } \\
\text { questionnaire }\end{array}$ & .959 & 18 & 289 \\
\hline $\begin{array}{l}\text { Guests } \\
\text { questionnaire }\end{array}$ & .975 & 16 & 648 \\
\hline
\end{tabular}

FirST: EMPLOYEES QUESTIONNAIRE:

Regarding Understanding the nature of the floating hotels employees profiles results are presented in table (3).

Table (3): Distribution of the respondents according to demographic $\operatorname{data}(\mathbf{n}=30)$

\begin{tabular}{|c|c|c|}
\hline Demographic data & No. & $\%$ \\
\hline \multicolumn{3}{|l|}{ Age } \\
\hline Under 20 years old & 45 & 15.6 \\
\hline From 20 to 38 years & 135 & 46.7 \\
\hline From 38 to 45 years & 87 & 30.1 \\
\hline Over 45 years old & 22 & 7.6 \\
\hline Total & 289 & 100.0 \\
\hline \multicolumn{3}{|l|}{ Gender } \\
\hline Male & 285 & 98.6 \\
\hline Female & 4 & 1.4 \\
\hline Total & 289 & 100.0 \\
\hline \multicolumn{3}{|l|}{ Social status } \\
\hline Single & 60 & 20.8 \\
\hline Married & 229 & 79.2 \\
\hline Total & 289 & 100.0 \\
\hline \multicolumn{3}{|l|}{ Education Level } \\
\hline Sub secondary & 9 & 3.1 \\
\hline High School & 51 & 17.6 \\
\hline
\end{tabular}




\begin{tabular}{|c|c|c|}
\hline $\begin{array}{c}\text { Above average } \\
\text { qualification }\end{array}$ & 90 & 31.1 \\
\hline High qualified & 119 & 41.2 \\
\hline Postgraduate & 20 & 6.9 \\
\hline Total & 289 & 100.0 \\
\hline Department & & \\
\hline Room divisions & 57 & 19.7 \\
\hline Entertainment team & 125 & 43.3 \\
\hline Food \& Beverage & 89 & 30.8 \\
\hline Other & 18 & 6.2 \\
\hline Total & 289 & 100.0 \\
\hline
\end{tabular}

- Concerning the ages (46.7\%) of the respondents were from (20) to (38) years old indicated that they are youth and have the power to exercise the entertainment activities.

- Data indicated that most of the respondents were male $(98.6 \%)$ this because in Upper Egypt in the floating hotels most of the staff are men because of traditions and the work nature.

- Regarding the social status most of the respondents were married (79.2\%) these indicate that they have responsibilities and families.

- The analysis clearly states that (41.2\%) of all respondents are high qualified educational level, whereas $31.1 \%$ of them were above moderate qualification this indicates that they are good mentality and able to learn.

- Concerning department $(43.3 \%)$ of the respondents were belong to $f$ entertainment team, whereas $30.8 \%$ of them food \& Beverage this indicates that in the floating hotels there is a cross training, round stations and round departments staff. 
Table (4): The employees' awareness level regarding the role of entertainment on guests' satisfaction

\begin{tabular}{|c|c|c|c|c|c|c|c|c|c|}
\hline \multirow{2}{*}{$\begin{array}{l}\dot{z} \\
\dot{0}\end{array}$} & \multirow[t]{2}{*}{ Answers } & \multicolumn{2}{|c|}{ Yes } & \multicolumn{2}{|c|}{ No } & \multicolumn{2}{|c|}{ Mean } & \multirow{2}{*}{ 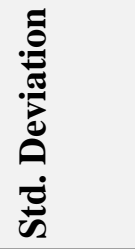 } & \multirow{2}{*}{ 苞 } \\
\hline & & Freq & $\%$ & Freq & $\%$ & Statistic & Std. Error & & \\
\hline Q1 & $\begin{array}{l}\text { Are the services } \\
\text { evaluated by the } \\
\text { entertainment } \\
\text { provided? }\end{array}$ & 243 & 84.1 & 46 & 16 & 1.1592 & .02156 & .36647 & 1 \\
\hline Q2 & $\begin{array}{l}\text { Are employees } \\
\text { aware of the } \\
\text { importance role of } \\
\text { entertainment in the } \\
\text { guests' satisfaction? }\end{array}$ & 219 & 75.8 & 70 & 24 & 1.2422 & .02525 & .42917 & 2 \\
\hline
\end{tabular}


Table (4) shows that most of the respondents believe that the services evaluated by the entertainment provided with average (84.1\%) with Mean (1.15) and Std. Deviation (.366). followed in the second ranking rate with $(75.8 \%)$ their believe that employees aware of the importance of the role of entertainment in the satisfaction of the hotels guests, with Mean (1.24) and Std. Deviation (.42). Results indicate that there is a need to improve the employees' awareness regarding entertainment services to improve the impact of the entertainment in the guest satisfaction. This agreed with Lkhamtseden and Altanchimeg, 2017.

\section{THE CHOICES THAT MOST TRUTHFULLY TELLS HOW THE EMPLOYEES FEEL ABOUT THOSE STATEMENTS}

Employees feeling about those statements: Table (5) Clarify whether the respondents strongly disagree (1), strongly agree (5) using 1-5 Likart scale. In order to list the mean scores of the respondents' opinion, the results showed that:

A. Concerning the employees opinion toward the first part: evaluating entertainment services, the results showed that:

1. Performance evaluation works on selecting the right human elements to work in entertainment and identify the actions to be implemented and distributed are the first efficiency average by percentage of $(96.89 \%)$, with a mean (4.84) and Std (0.36). this show that the importance of entertainment team selections.

2. Regarding the second agree rank was the continuous evaluation and assessment reduces the risk of errors by a percentage of (93.77\%) with a mean (4.89) and Std (0.25). this results showed that the importance of evaluation for safety and satisfaction.

3. In the third rank level was evaluation guides efforts to implement plans for the entertainment programs by a percentage of $(92.73 \%)$ as agree average, with a mean (4.63) and Std (0.48). results showed the importance of planning.

4. Concerning the fourth level agrees average was (91.49\%) regarding agree with that the assessment identifies weaknesses and imbalances in entertainment activity, and develops solutions to these errors. With mean (4.57) and Std (0.49). This indicate the importance of the continuous evaluating and developing.

5. In the fifth rank was performance appraisal provides feedback to employees about their responsibilities to increase guest satisfaction, by a percentage of $(81.52 \%)$ as agree average, with a mean (4.07) and Std (0.68). results indicate the employee awareness regarding the responsibility of guest satisfaction need to improved.

These results indicated that performance evaluation works on selecting the right human elements affects the guest satisfaction; the continuous 
evaluation and assessment reduces the risk is required; evaluation guides efforts to implement plans for the entertainment division; the assessment identifies weaknesses and develops solutions to these errors; Performance appraisal provides feedback to employees about their responsibilities to act on guest satisfaction. These results agreed with Hill et al., (2007); and Tong, (2015).

B. Concerning the employees' opinion toward the theme 2: Improving the level of entertainment services the results showed that:

1. In accordance to the first acceptance average level was the entertainment and leisure activities offered in the floating hotels have varied as each guest chooses his favorite activities. With $(96.89 \%)$ average, mean (4.84) and Std (0.36). this indicate the importance of variety of the entertainment activities.

2. In the second rank was that modern methods which are used in the process of assessing guest satisfaction with entertainment. By a percentage of (95.64\%) as agree average, with a mean (4.78) and Std (0.41). this indicate the importance of assuring guest satisfaction regarding the entertainment services.

3. There is continuing training and development for the entertainment services in the third priority to the respondents with agree average level (94.39\%) mean was (4.72) and Std (0.45). results show the importance of training and development of entertainment team and programs.

4. Followed in the fourth importance with (93.77\%) as an acceptance average by the hotel has a health club with modern equipment and a trained team, with a mean (4.68) and Std (0.46). the results show the importance of the entertainment equipment's and tools.

5. Concerning the fifth agree level was the hotel has many activities such as tennis, billiards, games, and health club by average ( $89.62 \%)$, with Std (0.66) and mean (4.48). the results show that the entertainment activities need more variety.

These results indicated that regarding improving the level of entertainment services important factors are: the entertainment and leisure activities' offered in the floating hotel have varied as each guest chooses his favorite activities; Modern methods are used in the process of assessing guest satisfaction with entertainment; continuous training and development to increase the level of entertainment services; the hotel has a health club with modern equipment and trained team; the hotel has many activities such as tennis, billiards, games, and health club. these results agreed with Heidbrink, (2019). 
C. Concerning the employees' opinion toward Part 3: The impact and importance of the role of entertainment services the results showed that:

1. In accordance to the first acceptance average level was attention to entertainment helps to increase guest satisfaction with hotel services. With (96.47\%) average, mean (4.82) and Std (0.38). results show that the importance of attention to increase guest satisfaction. this indicate the impact of entertainment on guest satisfaction.

2. Concerning the second level agrees average was $(82.70 \%)$ regarding agree with that the quality of the hotels entertainment services is related to guest satisfaction from the hotel with mean (4.86) and Std (0.34). this indicate the importance of the quality of entertainment programs. this indicate the importance of quality of the hotels entertainment programs. 


\section{Table (5) the employees feeling about those statements:}

\begin{tabular}{|c|c|c|c|c|c|c|c|c|c|c|c|c|c|c|c|c|c|}
\hline \multirow[t]{2}{*}{ No. } & \multirow[t]{2}{*}{ Scale Item } & \multicolumn{2}{|c|}{$\begin{array}{l}\text { Strongly } \\
\text { disagree }\end{array}$} & \multicolumn{2}{|c|}{ Disagree } & \multicolumn{2}{|c|}{ Uncertain } & \multicolumn{3}{|c|}{ agree } & $\begin{array}{c}\text { Strongly } \\
\text { agree }\end{array}$ & \multicolumn{2}{|c|}{ Mean } & \multirow[t]{2}{*}{ 远芯 } & \multirow{2}{*}{ 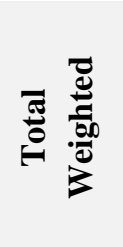 } & \multirow{2}{*}{ 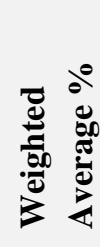 } & \multirow[t]{2}{*}{ Е } \\
\hline & & 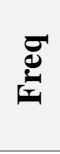 & $\Delta^{2}$ & ?્己 & $\Delta^{2}$ & ت्d & $\Delta^{0}$ & 总 & $\Delta^{e}$ & '્d & $b^{2}$ & 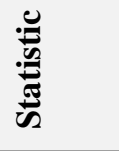 & 总苛 & & & & \\
\hline \multicolumn{18}{|c|}{ Evaluating entertainment services } \\
\hline 1. & $\begin{array}{l}\text { The continuous evaluation } \\
\text { and assessment reduces the } \\
\text { risk of errors }\end{array}$ & 0 & 0 & 0 & 0 & 0 & 0 & 90 & 31 & 199 & 69 & 4.896 & 0.015 & 0.257 & 1355 & 93.77 & 2 \\
\hline 2. & $\begin{array}{l}\text { The evaluation guides } \\
\text { efforts to implement plans } \\
\text { for the entertainment } \\
\text { division }\end{array}$ & 0 & 0 & 0 & 0 & 0 & 0 & 105 & 36 & 184 & 64 & 4.637 & 0.028 & 0.482 & 1340 & 92.73 & 3 \\
\hline 3. & $\begin{array}{l}\text { The assessment identifies } \\
\text { weaknesses and imbalances } \\
\text { in entertainment activity, } \\
\text { and develops solutions to } \\
\text { these errors }\end{array}$ & 0 & 0 & 0 & 0 & 0 & 0 & 123 & 43 & 166 & 57 & 4.574 & 0.029 & 0.495 & 1322 & 91.49 & 4 \\
\hline 4. & $\begin{array}{l}\text { Performance evaluation } \\
\text { works on selecting the right } \\
\text { human elements to work in } \\
\text { entertainment and identify } \\
\text { the actions to be } \\
\text { implemented and } \\
\text { distributed }\end{array}$ & 0 & 0 & 0 & 0 & 0 & 0 & 45 & 16 & 244 & 84 & 4.844 & 0.021 & 0.363 & 1400 & 96.89 & 1 \\
\hline
\end{tabular}




\begin{tabular}{|c|c|c|c|c|c|c|c|c|c|c|c|c|c|c|c|c|c|}
\hline 5. & $\begin{array}{l}\text { Performance appraisal } \\
\text { provides feedback to } \\
\text { employees about their } \\
\text { responsibilities to act on } \\
\text { guest satisfaction }\end{array}$ & 0 & 0 & 0 & 0 & 57 & 20 & 153 & 53 & 79 & 27 & 4.076 & 0.040 & 0.683 & 1178 & 81.52 & 5 \\
\hline \multicolumn{18}{|c|}{ Improving the level of entertainment services } \\
\hline 1. & $\begin{array}{l}\text { The hotel has a health club } \\
\text { with modern equipment and } \\
\text { trained team. }\end{array}$ & 0 & 0 & 0 & 0 & 0 & 0 & 90 & 31 & 199 & 69 & 4.689 & 0.027 & 0.464 & 1355 & 93.77 & 4 \\
\hline 2. & $\begin{array}{l}\text { The hotel has many } \\
\text { activities such as tennis, } \\
\text { billiards, games, and health } \\
\text { club. }\end{array}$ & 0 & 0 & 0 & 0 & 27 & 9 & 96 & 33 & 166 & 57 & 4.481 & 0.039 & 0.662 & 1295 & 89.62 & 5 \\
\hline 3. & $\begin{array}{l}\text { Entertainment and } \\
\text { entertainment activities } \\
\text { provided by the hotel is } \\
\text { suitable and matching the } \\
\text { guests }\end{array}$ & 0 & 0 & 0 & 0 & 84 & 29 & 144 & 50 & 61 & 21 & 3.920 & 0.041 & 0.705 & 1133 & 78.41 & 6 \\
\hline 4. & $\begin{array}{l}\text { Modern methods are used } \\
\text { in the process of assessing } \\
\text { guest satisfaction with } \\
\text { entertainment. }\end{array}$ & 0 & 0 & 0 & 0 & 0 & 0 & 63 & 22 & 226 & 78 & 4.782 & 0.024 & 0.414 & 1382 & 95.64 & 2 \\
\hline 5. & $\begin{array}{l}\text { There is continuous training } \\
\text { and development to } \\
\text { increase the level of } \\
\text { entertainment services. }\end{array}$ & 0 & 0 & 0 & 0 & 0 & 0 & 81 & 28 & 208 & 72 & 4.720 & 0.026 & 0.450 & 1364 & 94.39 & 3 \\
\hline 6. & $\begin{array}{l}\text { The entertainment and } \\
\text { leisure activities offered in } \\
\text { the floating hotel have } \\
\text { varied as each guest } \\
\text { chooses his favorite } \\
\text { activities. }\end{array}$ & 0 & 0 & 0 & 0 & 0 & 0 & 45 & 16 & 244 & 84 & 4.844 & 0.021 & 0.363 & 1400 & 96.89 & 1 \\
\hline \multicolumn{18}{|c|}{ The impact of the role of entertainment services } \\
\hline 1. & $\begin{array}{l}\text { The satisfaction of guests } \\
\text { with the level of services } \\
\text { improve the team morale, }\end{array}$ & 0 & 0 & 0 & 0 & 0 & 0 & 277 & 96 & 12 & 4 & 4.959 & 0.012 & 0.200 & 1168 & 80.83 & 5 \\
\hline
\end{tabular}


International Journal of Tourism and Hospitality Management Volume 3, Issue 1, June 2020

\begin{tabular}{|c|c|c|c|c|c|c|c|c|c|c|c|c|c|c|c|c|c|}
\hline & pride and self-steam & & & & & & & & & & & & & & & & \\
\hline 2. & $\begin{array}{l}\text { Entertainment brings } \\
\text { satisfaction, joy and fun to } \\
\text { hotel guests }\end{array}$ & 0 & 0 & 0 & 0 & 0 & 0 & 271 & 94 & 18 & 6 & 4.938 & 0.014 & 0.242 & 1174 & 81.25 & 4 \\
\hline 3. & $\begin{array}{l}\text { Entertainment aims the } \\
\text { guest happiness and that } \\
\text { there are satisfaction and } \\
\text { happiness gained by the } \\
\text { guest through the exercise } \\
\text { of entertainment activities. }\end{array}$ & 0 & 0 & 0 & 0 & 0 & 0 & 259 & 90 & 30 & 10 & 4.896 & 0.018 & 0.306 & 1186 & 82.08 & 3 \\
\hline 4. & $\begin{array}{l}\text { The quality of hotels } \\
\text { entertainment services is } \\
\text { related to guest satisfaction } \\
\text { from the hotel }\end{array}$ & 0 & 0 & 0 & 0 & 0 & 0 & 250 & 87 & 39 & 14 & 4.865 & 0.020 & 0.342 & 1195 & 82.70 & 2 \\
\hline 5. & $\begin{array}{l}\text { Caring for entertainment } \\
\text { helps to increase guest } \\
\text { satisfaction with hotel } \\
\text { service }\end{array}$ & 0 & 0 & 0 & 0 & 0 & 0 & 51 & 18 & 238 & 82 & 4.824 & 0.022 & 0.382 & 1394 & 96.47 & 1 \\
\hline
\end{tabular}


3. Regarding entertainment aims the guest happiness and that there are satisfaction and happiness gained by the guest through the exercise of entertainment activities. Achieved the third level by average acceptance $(82.08 \%)$ with a mean (4.89) and Std (0.30). this show the role of entertainment in guest happiness.

4. Regarding entertainment brings satisfaction, joy and fun to hotel guests achieved the fourth level by average acceptance (81.25\%) with mean (4.93) and Std (0.24). results show the role of entertainment in the guest satisfaction, joy and fun.

5. In the fifth rank was that satisfaction of guests with the level of services improve the team morale, pride and self-steam, by a percentage of $(80.83 \%)$ as agree average, with a mean (4.95) and Std (0.20). results show the impact of entertainment to improve the team morale, pride and self-steam.

These results indicated that regarding the impact and importance of the role of entertainment services vital factors are: attention to entertainment helps to increase guest satisfaction with hotel service; the quality of the hotel's entertainment services is related to guest satisfaction from the hotel; entertainment aims the guest happiness and that there are some feelings and contentment gained by the guest through the exercise of entertainment activities; entertainment brings satisfaction, joy and fun to hotels guests; the satisfactions of guests with the level of services improve the team morale, pride and self-steam. These results agreed with Tong, (2015), and Moital1, (2019).

\section{RESPONDENTS' OPINION REGARDING THE ADVANTAGES OF THE DIFFERENT FACTORS THAT MEASURE ENTERTAINMENT SERVICES IN THE FLOATING HOTELS IN LUXOR}

The following table illustrates the means, standard deviations and ranking of the factors clarifying the respondents' opinion regarding the advantages of different factors that measure entertainment services in floating hotels in Luxor as shown in table 6.

Table 6: Measure entertainment services in floating hotels in Luxor $(n=289)$

\begin{tabular}{|l|l|r|r|r|r|}
\hline No. & & Mean & $\begin{array}{c}\text { Std. } \\
\text { Deviation }\end{array}$ & Ranking & \\
\hline G1 & Evaluating entertainment services & 4.5640 & .02565 & .43599 & 3 \\
\hline G2 & $\begin{array}{l}\text { Improving the level of entertainment } \\
\text { services }\end{array}$ & 4.5727 & .02677 & .45507 & 2 \\
\hline G3 & $\begin{array}{l}\text { The impact and importance of the } \\
\text { role of entertainment services }\end{array}$ & 4.8962 & .01510 & .25662 & 1 \\
\hline
\end{tabular}


According to the previous table, the results show that the respondents are aware of the advantages of the different parts that measure entertainment services in floating hotels in Luxor and ranking them as follows: The impact and importance of the role of entertainment services were the first efficiency with a mean (4.89) and std. (0.25); Improving the level of entertainment services were in the second rank with a mean (4.56) and std. (.45); evaluating entertainment services were in the third rank with a mean (4.56) and std. (.43). These results agreed with Shujat et al., (2011).

\section{SECOND: GUESTS QUESTIONNAIRE:}

This information was useful in understanding the nature of Luxor Floating hotels guest profiles. Results are presented in table (7).

Table (7): Distribution of the respondents according to demographic data (n =30)

\begin{tabular}{|c|c|c|}
\hline Demographic data & No. & $\%$ \\
\hline \multicolumn{3}{|l|}{ Age } \\
\hline Under 20 years old & 36 & 5.6 \\
\hline From 20 to 38 years & 60 & 9.3 \\
\hline From 38 to 45 years & 95 & 14.7 \\
\hline Over 45 years old & 457 & 70.5 \\
\hline Total & 648 & 100.0 \\
\hline \multicolumn{3}{|l|}{ Gender } \\
\hline Male & 191 & 29.5 \\
\hline Female & 457 & 70.5 \\
\hline Total & 648 & 100.0 \\
\hline \multicolumn{3}{|l|}{ Nationality } \\
\hline English & 102 & 15.7 \\
\hline German & 299 & 46.1 \\
\hline Italian & 67 & 10.3 \\
\hline French & 78 & 12.0 \\
\hline Arabic & 66 & 10.2 \\
\hline Other & 36 & 5.6 \\
\hline Total & 648 & 100.0 \\
\hline \multicolumn{3}{|l|}{ Education Level } \\
\hline secondary & 228 & 35.2 \\
\hline Bachelor & 348 & 53.7 \\
\hline Other & 72 & 11.1 \\
\hline Total & 648 & 100.0 \\
\hline
\end{tabular}


- Concerning the ages $(70.5 \%)$ of the respondents are older than 45 years old.

- Data indicated that most of the respondents are female (70.5\%).

- Regarding the Nationality most of the respondents are German $(46.1 \%)$.

- Concerning Education Level (53.7\%) of the respondents were bachelors.

Table (8) shows the various factors that measure the guest satisfaction with the entertainment services

(5) Items about the impact of satisfaction with entertainment services in the floating hotels in Luxor, the results showed that:

A. Concerning the first part: Improving the level of entertainment services the result showed that:

1. The hotel is showing interest in providing you with a solution to the problems you may have at the hotel. The first strongly agree average by percentage of $(94.14 \%)$, with a mean (4.70) and Std (0.45). Results show that the hotels care about the guest and handling guest complains. These indicate that the importance of guest feedback and handling customers complains.

2. Regarding second agree average of the guest satisfaction is the entertainment team members should be fit, helpful, and friendly, pleased and have the sense of fun. By a percentage of (90.56\%) with a mean (4.52) and Std (0.65). This indicated that the entertainment team characters are very important for the guest satisfaction.

3. In the third rank were entertainment team members should be from different nationalities and skills and characteristics has high priorities by a percentage of (84.63\%) as agree average, with a mean (4.23) and Std (0.66). These results show the importance of the variety and difference of the entertainment team nationalities, skills and characteristics for satisfying the different guests.

4. In the fourth rank level there should be harmony among the employees of entertainment during the entertainment show by a percentage of (79.97\%) as agree average, with a mean (3.99) and Std (0.61). The team work and harmony is required.

5. In the fifth rank were entertainment teams are available and direct, support, help, and protect you, by a percentage of $(77.25 \%)$ as agree average, with a mean (3.86) and Std (0.55). The availability of entertainment team is very important. 
6. Regarding sixth agree average were there are entertainment programs and show for children inside the floating hotel by a percentage of (76.48\%) with a mean (3.82) and Std (0.38). The results show that children entertainment programs are very important factor.

7. In the seventh rank were the employee looks trained and able to introduce pleasure and joy and create a perfect entertainment atmosphere by a percentage of $(75.19 \%)$ as efficiency average, with a mean (3.75) and Std (0.42). Results show that training is avital factors in entertainment and need more care.

8. Regarding the eights rank level the guests find that the entertainment programs satisfy guest needs, wants, and requirements. With agree average weigh level (71.94\%), mean was (3.59) and Std (0.49). Results show that matching guest need is mandatory.

9. In the ninth rank level there are protective procedures for security and safety to prevent problems that may be caused by entertainment services, by a percentage of $(70.00 \%)$ as agree weighted average, with a mean (3.50) and Std (0.50). Results show that security and safety need more care.

10. Regarding the tenth agree average was there is a variety of entertainment programs and show presented by entertainment team by a percentage of $(65.56 \%)$ with a mean (3.27) and Std (0.44). The results show that entertainment programs need more variety.

11. Finally, in accordance to the eleventh acceptance average level were the hotel's services are a source of confidence and excellence with (59.44\%) average, mean (2.97) and Std (0.76). Results that guest need improvement.

These results indicated that regarding improving the level of entertainment services, energetic factors are: the hotel care about the guest and handling guest complain. This indicates that the importance of guest feedback and handling customer complain; the guest satisfaction is the entertainment team members should be fit, helpful, friendly, pleased, lightness and have the sense of fun; entertainment team should be from different nationalities and skills and characteristics have high priorities; there is harmony between the employees of entertainment during the entertainment show; entertainment team are available and direct, support, help, and protect the guest. These results agreed with Timpe, (2017), Heidbrink, (2019).

On the other hand these results indicate that regarding improving the level of entertainment services lowest level factors which need urgent care and improvement are: in the lowest rank level were the hotel's services are a source of confidence and excellence; there is a variety of entertainment programs and show offered by entertainment team; there are protective procedures for security and safety to prevent problems that may be caused by entertainment services ; The guest finds that the entertainment programs 
provide the services that satisfy guest needs, want, and requirements.; the employee is trained and able to introduce pleasure and joy and create a distinct entertainment atmosphere. These results disagreed with the guest expectation, satisfaction and with the previous researches (Davoud, and Hamed, 2012; Tong, 2015; Chen and Sun, 2019).

B. Concerning the second part: the influence of satisfaction with entertainment services the result showed that:

1. In the first rank level is the guest level of satisfaction with entertaining services is affected by level of safety and comfort by a percentage of $(98.89 \%)$ as agree weighted average, with a mean (4.94) and Std (0.22). Results show that safety first.

2. Regarding the second agree average was the level of guest satisfaction with entertainment services generates overall satisfaction and retention by a percentage of (98.33\%) with a mean (4.91) and Std (0.27). Results show the impact of entertainment programs on guest satisfaction.

3. In the third rank level was the guest expectation to repurchase depends on rating of the hotel which is affected by the level of services provided by a percentage of $(97.22 \%)$ as efficiency average, with a mean (4.86) and Std (0.34). Results show that entertainment programs affect the guest expectation to repurchase.

4. Concerning the fourth level agrees average was (96.48\%) regarding agree with that the guest return again will be affected by guest satisfaction with its entertainment services with mean (4.82) and Std (0.38). Results show that guest satisfaction with its entertainment services affect guest return again.

5. In accordance to the fifth acceptance average level was that guest recommend the hotel to others will be affected by guest satisfaction with its entertainment services. With (95.43\%) average, mean (4.77) and Std (0.42). Results show that satisfaction with its entertainment services affect guest recommend the hotel to others. 


\begin{tabular}{|c|c|c|c|c|c|c|c|c|c|c|c|c|c|c|c|c|c|}
\hline \multirow{2}{*}{$\dot{0}$} & \multirow{2}{*}{ نَّ } & \multirow[t]{2}{*}{ Scale Item } & \multicolumn{2}{|c|}{ 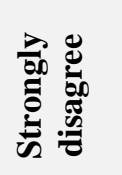 } & \multicolumn{2}{|l|}{ 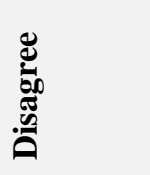 } & \multicolumn{2}{|l|}{ 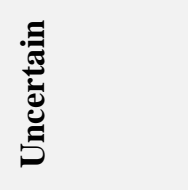 } & \multicolumn{2}{|l|}{ 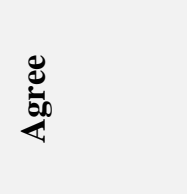 } & \multicolumn{2}{|c|}{ 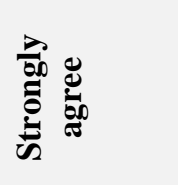 } & \multicolumn{2}{|c|}{ Mean } & \multirow{2}{*}{ 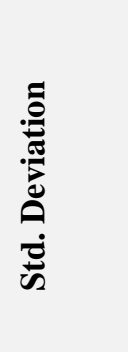 } & \multirow{2}{*}{ 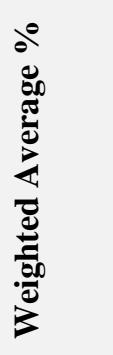 } & \multirow{2}{*}{ 气ै } \\
\hline & & & E్d & be & E్d & be & $\underset{\square}{\mathbb{D}}$ & $b^{2}$ & $\underset{D}{\mathbb{D}}$ & $b^{e}$ & 总 & $b^{2}$ & 莺 & 苟苛 & & & \\
\hline \multicolumn{18}{|c|}{ The level of entertainment services } \\
\hline 1. & A1 & $\begin{array}{l}\text { The hotel is showing } \\
\text { interest in solving } \\
\text { problems you may have } \\
\text { in the hotel. }\end{array}$ & 0 & 0 & 0 & 0 & 0 & 0 & 190 & 29 & 458 & 71 & 4.7068 & .01790 & .45559 & 94.14 & 1 \\
\hline 2. & A2 & $\begin{array}{l}\text { You find that the } \\
\text { entertainment programs } \\
\text { satisfy your needs, want, } \\
\text { and requirements. }\end{array}$ & 0 & 0 & 0 & 0 & 261 & 40 & 387 & 60 & 0 & 0 & 3.5972 & .01928 & .49084 & 71.94 & 8 \\
\hline 3. & A3 & $\begin{array}{l}\text { There are protective } \\
\text { procedures for security } \\
\text { and safety to prevent } \\
\text { problems that may be } \\
\text { caused by entertainment } \\
\text { services }\end{array}$ & 0 & 0 & 0 & 0 & 324 & 50 & 324 & 50 & 0 & 0 & 3.5000 & .01966 & .50039 & 70.00 & 9 \\
\hline 4. & A4 & $\begin{array}{l}\text { Entertainment team } \\
\text { members are available. } \\
\text { They direct, support, } \\
\text { help, and protect you }\end{array}$ & 0 & 0 & 0 & 0 & 149 & 23 & 439 & 68 & 60 & 9 & 3.8627 & 02166 & .55149 & 77.25 & 5 \\
\hline
\end{tabular}




\begin{tabular}{|c|c|c|c|c|c|c|c|c|c|c|c|c|c|c|c|c|c|}
\hline 5. & A5 & $\begin{array}{l}\text { The hotel's services are } \\
\text { a source of confidence } \\
\text { and excellence }\end{array}$ & 0 & 0 & 198 & 31 & 270 & 42 & 180 & 28 & 0 & 0 & 2.9722 & .03001 & .76385 & 59.44 & 11 \\
\hline 6. & A6 & $\begin{array}{l}\text { There is a variety of } \\
\text { entertainment programs } \\
\text { and show presented by } \\
\text { entertainment team }\end{array}$ & 0 & 0 & 0 & 0 & 468 & 72 & 180 & 28 & 0 & 0 & 3.2778 & .01761 & .44825 & 65.56 & 10 \\
\hline 7. & A7 & $\begin{array}{l}\text { The entertainment team } \\
\text { comprises different } \\
\text { nationalities, skills and } \\
\text { characteristics }\end{array}$ & 0 & 0 & 0 & 0 & 84 & 13 & 330 & 51 & 234 & 36 & 4.2315 & .02599 & 66169 & 84.63 & 3 \\
\hline 8. & A8 & $\begin{array}{l}\text { There are harmony } \\
\text { between the employees } \\
\text { of entertainment during } \\
\text { the entertainment show }\end{array}$ & 0 & 0 & 0 & 0 & 121 & 19 & 407 & 63 & 120 & 19 & 3.9985 & .02398 & .61032 & 79.97 & 4 \\
\hline 9. & A9 & $\begin{array}{l}\text { The employee looks } \\
\text { trained and is able to } \\
\text { introduce pleasure and } \\
\text { joy and create a perfect } \\
\text { entertainment } \\
\text { atmosphere }\end{array}$ & 0 & 0 & 0 & 0 & 156 & 24 & 492 & 76 & 0 & 0 & 3.7593 & .01681 & .42786 & 75.19 & 7 \\
\hline 10. & A10 & $\begin{array}{l}\text { The entertainment team } \\
\text { members should be fit, } \\
\text { helpful, friendly, } \\
\text { smiling, and light and } \\
\text { have the sense of fun. }\end{array}$ & 0 & 0 & 0 & 0 & 60 & 9 & 186 & 29 & 402 & 62 & 4.5278 & .02591 & .65961 & 90.56 & 2 \\
\hline 11. & A11 & $\begin{array}{l}\text { There are entertainment } \\
\text { programs and show for } \\
\text { children inside the hotel }\end{array}$ & 0 & 0 & 0 & 0 & 114 & 18 & 534 & 82 & 0 & 0 & 3.8241 & .01497 & .38105 & 76.48 & 6 \\
\hline \multicolumn{18}{|c|}{ The influence of satisfaction with entertainment services } \\
\hline 1. & B1 & $\begin{array}{l}\text { Your level of } \\
\text { satisfaction with } \\
\text { entertaining services is } \\
\text { affected by your level of } \\
\text { safety and comfort }\end{array}$ & 0 & 0 & 0 & 0 & 0 & 0 & 36 & 6 & 612 & 94 & 4.9444 & .00901 & .22924 & 98.89 & 1 \\
\hline
\end{tabular}




\begin{tabular}{|c|c|c|c|c|c|c|c|c|c|c|c|c|c|c|c|c|c|}
\hline 2. & B2 & $\begin{array}{l}\text { Your level of } \\
\text { satisfaction with } \\
\text { entertainment services } \\
\text { affects overall } \\
\text { satisfaction and } \\
\text { retention }\end{array}$ & 0 & 0 & 0 & 0 & 0 & 0 & 54 & 8 & 594 & 92 & 4.9167 & .01087 & .27660 & 98.33 & 2 \\
\hline 3. & B3 & $\begin{array}{l}\text { Expectations to } \\
\text { repurchase depend on } \\
\text { rating of the hotel } \\
\text { which is affected by the } \\
\text { level of services } \\
\text { provided }\end{array}$ & 0 & 0 & 0 & 0 & 0 & 0 & 90 & 14 & 558 & 86 & 4.8611 & .01360 & .34610 & 97.22 & 3 \\
\hline 4. & B4 & $\begin{array}{l}\text { Your return again will } \\
\text { be affected by your } \\
\text { satisfaction with its } \\
\text { entertainment services }\end{array}$ & 0 & 0 & 0 & 0 & 0 & 0 & 114 & 18 & 534 & 82 & 4.8241 & .01497 & .38105 & 96.48 & 4 \\
\hline 5. & B5 & $\begin{array}{l}\text { Your satisfaction with } \\
\text { the hotel and } \\
\text { recommend to others } \\
\text { will be affected by your } \\
\text { satisfaction with its } \\
\text { entertainment services }\end{array}$ & 0 & 0 & 0 & 0 & 0 & 0 & 148 & 23 & 500 & 77 & 4.7716 & .01650 & .42012 & 95.43 & 5 \\
\hline
\end{tabular}


These results indicate that regarding the impact of satisfaction with entertainment services vital factors are: the level of guest satisfaction with entertaining services is affected by level of safety and comfort; the level of guest satisfaction with entertainment services generates overall satisfaction and retention; the hotel is affected by the level of services provided; the guest return again will be affected by guest satisfaction with its entertainment services; guest satisfaction with the hotel and its publicity will be affected by guest satisfaction. These results agreed with Luo and Lam, (2017).

Prior to research reliability, it is important to establish the reliability of each of the items used in this study. Descriptive Statistics, Means, Standard deviation. Moreover, One-Sample Test (T - test) in table (9) used to compare means to show the values differences: 
Table 9: One-Sample Test ( $\mathrm{T}$ - test) used to compare means

\begin{tabular}{|c|c|c|c|c|c|c|c|c|c|}
\hline \multirow{2}{*}{\multicolumn{4}{|c|}{ One-Sample Statistics }} & \multirow{2}{*}{\multicolumn{6}{|c|}{$\begin{array}{c}\text { One-Sample Test } \\
\text { Test Value }=5\end{array}$}} \\
\hline & & & & & & & & & \\
\hline \multirow{2}{*}{ Code } & \multirow[t]{2}{*}{ Mean } & \multirow{2}{*}{ 它 } & \multirow{2}{*}{ 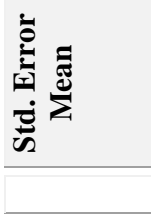 } & \multirow[t]{2}{*}{$\mathbf{t}$} & \multirow[t]{2}{*}{ df } & \multirow{2}{*}{ 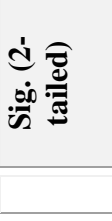 } & \multirow{2}{*}{ 离 } & \multicolumn{2}{|c|}{$\begin{array}{l}\text { 95\% Confidence Interval o } \\
\text { the Difference }\end{array}$} \\
\hline & & & & & & & & Lower & Upper \\
\hline A1 & 4.7068 & .45559 & .01790 & $-16.383-$ & 647 & .000 & $-.29321-$ & $-.3284-$ & $-.2581-$ \\
\hline $\mathrm{A} 2$ & 3.5972 & .49084 & .01928 & $-72.751-$ & 647 & .000 & $-1.40278-$ & $-1.4406-$ & $-1.3649-$ \\
\hline $\mathrm{A} 3$ & 3.5000 & .50039 & .01966 & $-76.309-$ & 647 & .000 & $-1.50000-$ & $-1.5386-$ & $-1.4614-$ \\
\hline A4 & 3.8627 & .55149 & .02166 & -52.498 & 647 & .000 & $-1.13735-$ & $-1.1799-$ & $-1.0948-$ \\
\hline A5 & 2.9722 & .76385 & .03001 & $-67.577-$ & 647 & .000 & $-2.02778-$ & $-2.0867-$ & $-1.9689-$ \\
\hline A6 & 3.2778 & .44825 & .01761 & $-97.804-$ & 647 & .000 & $-1.72222-$ & $-1.7568-$ & $-1.6876-$ \\
\hline A7 & 4.2315 & .66169 & .02599 & $-29.566-$ & 647 & .000 & $-.76852-$ & $-.8196-$ & $-.7175-$ \\
\hline A8 & 3.9985 & .61032 & .02398 & $-41.774-$ & 647 & .000 & $-1.00154-$ & $-1.0486-$ & $-.9545-$ \\
\hline A9 & 3.7593 & .42786 & .01681 & $-73.818-$ & 647 & .000 & $-1.24074-$ & $-1.2737-$ & $-1.2077-$ \\
\hline A10 & 4.5278 & .65961 & .02591 & $-18.224-$ & 647 & .000 & $-.47222-$ & $-.5231-$ & $-.4213-$ \\
\hline A11 & 3.8241 & .38105 & .01497 & -78.557- & 647 & .000 & $-1.17593-$ & $-1.2053-$ & $-1.1465-$ \\
\hline B1 & 4.9444 & .22924 & .00901 & $-6.169-$ & 647 & .000 & $-.05556-$ & $-.0732-$ & $-.0379-$ \\
\hline B2 & 4.9167 & .27660 & .01087 & $-7.669-$ & 647 & .000 & $-.08333-$ & $-.1047-$ & $-.0620-$ \\
\hline B3 & 4.8611 & .34610 & .01360 & $-10.215-$ & 647 & .000 & $-.13889-$ & $-.1656-$ & $-.1122-$ \\
\hline B4 & 4.8241 & .38105 & .01497 & $-11.753-$ & 647 & .000 & $-.17593-$ & $-.2053-$ & $-.1465-$ \\
\hline B5 & 4.7716 & .42012 & .01650 & -13.839 & 647 & .000 & $-.22840-$ & $-.2608-$ & $-.1960-$ \\
\hline
\end{tabular}


Respondents' opinions regarding the various factors that measure the guest satisfaction with the entertainment services in floating hotels in Luxor Table 10: Clarify the guests' opinion regarding assessment of the satisfaction of the guest with the entertainment services in floating hotels in Luxor $(n=648)$.

Table 10: The guests' opinion in floating hotels in Luxor $(n=648)$

\begin{tabular}{|c|c|c|c|c|c|}
\hline \multirow[t]{2}{*}{ Code } & & \multicolumn{2}{|c|}{ Mean } & \multirow{2}{*}{$\begin{array}{c}\text { Std. Deviation } \\
\text { Statistic }\end{array}$} & \multirow[b]{2}{*}{ 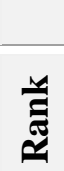 } \\
\hline & & Statistic & $\begin{array}{l}\text { Std. } \\
\text { Error }\end{array}$ & & \\
\hline Part1 & $\begin{array}{l}\text { The level of } \\
\text { entertainment } \\
\text { services }\end{array}$ & 3.8416 & .01809 & .46051 & 2 \\
\hline Part2 & $\begin{array}{l}\text { The impact of } \\
\text { satisfaction } \\
\text { with } \\
\text { entertainment } \\
\text { services }\end{array}$ & 4.8636 & .01131 & .28788 & 1 \\
\hline
\end{tabular}

According to the previous table, the results show that the respondents are aware of the entertainment services in floating hotels in Luxor and ranking them as follows: the impact of satisfaction with entertainment services was in the first rank level with a mean (4.86) and std. (.28). Followed by assessments of the level of entertainment services were the second efficiency with a mean (4.84) and std. (0.46) this indicating the importance of the entertainment services.

Research hypotheses were tested using Pearson correlation coefficient. Preliminary analyses were performed to ensure no violation of assumptions of normality and linearity. Table (11) shows that there are very strong correlations between all proposed relations in the conceptual hypotheses, with $(\mathrm{r})$ values ranging from $(.704)$ to $(.974)(\mathrm{p}<.005)$ and the obtained correlation values are in the expected positive direction. Based on the results of Pearson correlation analysis which represent proposed linear relationship, all the research hypotheses were fully supported, the following table illustrates that: 
Table (11) Correlation analysis and Hypotheses testing

\begin{tabular}{|c|c|c|c|c|c|}
\hline No. & Hypothesized Correlation & モี & 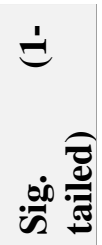 & $\mathbf{Z}$ & 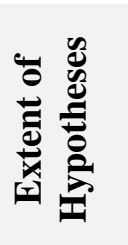 \\
\hline H1A & $\begin{array}{l}\text { There is statistically significant } \\
\text { relationship between the } \\
\text { evaluating entertainment services } \\
\text { vs the improving the level of } \\
\text { entertainment services. }\end{array}$ & $.974 * *$ & .000 & 289 & $\begin{array}{l}\text { Very } \\
\text { strong }\end{array}$ \\
\hline H1B & $\begin{array}{l}\text { There is statistically significant } \\
\text { relationship between the } \\
\text { evaluating entertainments services } \\
\text { vs the impact of the role of } \\
\text { entertainment services. }\end{array}$ & $.704 * *$ & .000 & 289 & $\begin{array}{l}\text { Very } \\
\text { strong }\end{array}$ \\
\hline $\mathrm{H} 1 \mathrm{C}$ & $\begin{array}{l}\text { There is statistically significant } \\
\text { relationship between improving } \\
\text { the level of entertainment services } \\
\text { vs the impact and importance of } \\
\text { the role of entertainment services }\end{array}$ & $.764 * *$ & .000 & 289 & $\begin{array}{l}\text { Very } \\
\text { strong }\end{array}$ \\
\hline $\mathrm{H} 2$ & $\begin{array}{l}\text { There is statistically significant } \\
\text { relationship between the } \\
\text { entertainment programs Vs the } \\
\text { guest satisfaction }\end{array}$ & $.731 * *$ & .000 & 648 & $\begin{array}{l}\text { Very } \\
\text { strong }\end{array}$ \\
\hline
\end{tabular}

Note $* *$ correlation is significant at the 0.001 level.

$\mathrm{H} 2$ : There is statistically significant impact of the entertainment programs on the guest satisfaction

The second hypotheses were tested using NPar Tests "Kruskal-Wallis Test". Test Statistics, b (a. Kruskal Wallis Test for The level of entertainment services and b. Grouping Variable: Part2 The influence of satisfaction with entertainment services). Results shows that there is strong impact of the entertainment programs on guest satisfaction, with (Chi-Square) values ranging from (161.715) to (541.220); Asymp. Sig. (.000) this indicate there is statistically significant relations. As shown in table (12) 
Table (12) The impact of the entertainment programs on the guest satisfaction NPar Tests

\begin{tabular}{|c|c|c|c|c|c|c|}
\hline \multirow[b]{2}{*}{ ن் } & \multicolumn{4}{|c|}{ Ranks } & \multicolumn{2}{|c|}{ Test Statistics $^{a, b}$} \\
\hline & & Part2 & $\mathbf{N}$ & 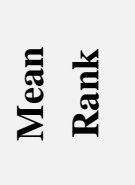 & 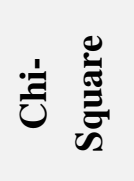 & 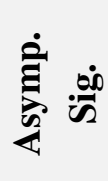 \\
\hline \multirow[t]{2}{*}{11} & \multirow{2}{*}{$\begin{array}{l}\text { The hotel is showing interest in solving } \\
\text { problems you may have in the hotel. }\end{array}$} & 4.00 & 148 & 95.50 & \multirow[t]{2}{*}{461.645} & \multirow{2}{*}{.000} \\
\hline & & 5.00 & 500 & 392.28 & & \\
\hline \multirow[t]{2}{*}{$\mathrm{A} 2$} & \multirow{2}{*}{$\begin{array}{l}\text { You find that the entertainment } \\
\text { programs satisfy your needs, want, and } \\
\text { requirements. }\end{array}$} & 4.00 & 148 & 144.14 & \multirow[t]{2}{*}{246.722} & \multirow{2}{*}{.000} \\
\hline & & 5.00 & 500 & 377.89 & & \\
\hline \multirow[t]{2}{*}{$\mathrm{A} 3$} & \multirow{2}{*}{$\begin{array}{l}\text { There are protective procedures for } \\
\text { security and safety to prevent problems } \\
\text { that may be caused by entertainment } \\
\text { services }\end{array}$} & 4.00 & 148 & 175.64 & \multirow[t]{2}{*}{161.715} & \multirow[b]{2}{*}{.000} \\
\hline & & 5.00 & 500 & 368.56 & & \\
\hline \multirow[t]{2}{*}{ A4 } & \multirow{2}{*}{$\begin{array}{l}\text { Entertainment team members are } \\
\text { available. They direct, support, help, } \\
\text { and protect you }\end{array}$} & 4.00 & 148 & 97.03 & \multirow[t]{2}{*}{418.833} & \multirow{2}{*}{.000} \\
\hline & & 5.00 & 500 & 391.83 & & \\
\hline \multirow[t]{2}{*}{ A5 } & \multirow{2}{*}{$\begin{array}{l}\text { The hotel's services are a source of } \\
\text { confidence and excellence }\end{array}$} & 4.00 & 148 & 118.11 & \multirow[t]{2}{*}{265.623} & \multirow{2}{*}{.000} \\
\hline & & 5.00 & 500 & 385.59 & & \\
\hline \multirow[t]{2}{*}{ A6 } & \multirow{2}{*}{$\begin{array}{l}\text { There is a variety of entertainment } \\
\text { programs and show presented by } \\
\text { entertainment team }\end{array}$} & 4.00 & 148 & 247.64 & \multirow[t]{2}{*}{53.727} & \multirow{2}{*}{.000} \\
\hline & & 5.00 & 500 & 347.25 & & \\
\hline
\end{tabular}




\section{International Journal of Tourism and Hospitality Management Volume 3, Issue 1, June 2020}

\begin{tabular}{|c|c|c|c|c|c|c|}
\hline \multirow[t]{2}{*}{ A7 } & \multirow{2}{*}{$\begin{array}{l}\text { The entertainment team comprises } \\
\text { different nationalities, skills and } \\
\text { characteristics }\end{array}$} & 4.00 & 148 & 132.01 & \multirow[t]{2}{*}{247.699} & \multirow{2}{*}{.000} \\
\hline & & 5.00 & 500 & 381.48 & & \\
\hline \multirow[t]{2}{*}{ A8 } & \multirow{2}{*}{$\begin{array}{l}\text { There are harmony between the } \\
\text { employees of entertainment during the } \\
\text { entertainment show }\end{array}$} & 4.00 & 148 & 109.16 & \multirow[t]{2}{*}{343.250} & \multirow{2}{*}{.000} \\
\hline & & 5.00 & 500 & 388.24 & & \\
\hline \multirow[t]{2}{*}{ A9 } & \multirow{2}{*}{$\begin{array}{l}\text { The employee looks trained and is able } \\
\text { to introduce pleasure and joy and create } \\
\text { a perfect entertainment atmosphere }\end{array}$} & 4.00 & 148 & 91.64 & \multirow[t]{2}{*}{541.220} & \multirow{2}{*}{.000} \\
\hline & & 5.00 & 500 & 393.43 & & \\
\hline \multirow{2}{*}{$\begin{array}{l}\text { A1 } \\
0\end{array}$} & \multirow{2}{*}{$\begin{array}{l}\text { The entertainment team members should } \\
\text { be fit, helpful, friendly, smiling, and } \\
\text { light and have the sense of fun. }\end{array}$} & 4.00 & 148 & 103.64 & \multirow[t]{2}{*}{362.351} & \multirow{2}{*}{.000} \\
\hline & & 5.00 & 500 & 389.88 & & \\
\hline \multirow{2}{*}{$\begin{array}{l}\text { A1 } \\
1\end{array}$} & \multirow{2}{*}{$\begin{array}{l}\text { There are entertainment programs and } \\
\text { show for children inside the hotel }\end{array}$} & 4.00 & 148 & 131.93 & \multirow[t]{2}{*}{466.634} & \multirow{2}{*}{.000} \\
\hline & & 5.00 & 500 & 381.50 & & \\
\hline
\end{tabular}

\section{a. Kruskal Wallis Test}

b. Grouping Variable: Part2 


\section{Conclusions}

Concerning the employees' opinion towards evaluating entertainment services the results showed that: the importance of variety of the entertainment activities; and assuring guest satisfaction; the importance of training and development of entertainment team and programs; the entertainment equipment's and tools; the entertainment activities need more variety. These results agreed with Tong, (2015).

Concerning the employees' opinion towards improving the level of entertainment services the results showed that: In accordance to the first acceptance average level was the entertainment and leisure activities presented in the floating hotel have varied as each guest chooses his favorite activities. Followed by Modern methods are used in the process of assessing guest satisfaction with entertainment. These indicate the importance of variety of the entertainment activities; assuring guest satisfaction regarding the entertainment services; the importance of training and development of entertainment team and programs; the importance of the entertainment equipment's and tools; the results show that the entertainment activities need more variety this results agreed with Heidbrink, (2019).

Concerning the employees' opinion towards the impact and importance of the role of entertainment services the results showed that: In accordance to the first acceptance average level was Attention to entertainment helps to increase guest satisfaction with hotel service. Followed by quality of the hotel's entertainment services is related to guest satisfaction with the hotel. Results indicate the impact of entertainment on guest satisfaction, the importance of quality of the hotels entertainment programs, the role of entertainment in guest happiness, satisfaction, joy and fun; The impact of entertainment to improve the team morale, pride and self-steam. this results agreed with Hill et al., (2007); and Tong, (2015).

The respondents are aware of the advantages of the different parts that measure entertainment services in floating hotels in Luxor and ranking them as follows: The impact and importance of the role of entertainment services were the first efficiency; Improving the level of entertainment services were in the second rank level; evaluating entertainment services were in the third rank level these results agreed with Shujat et al., (2011). Regarding, the various parts that measure the guest satisfaction with the entertainment services the results showed that: Concerning the level of entertainment services. The hotel is showing interest in providing you with a solution to the problems you may have at the hotel. Results show that the hotels care about the guest and handling guest complains. These indicate that the importance of guest feedback and handling customers complains. Followed by the guest satisfaction is the entertainment team members 
should be fit, helpful, friendly, pleased, and light and have the sense of fun. This indicated that the entertainment team characters are very important for the guest satisfaction.

Moreover results show the importance of the variety and difference of the entertainment team nationalities, skills and characteristics for satisfying the different guests; The team work and harmony is required; The availability of entertainment team is very important; children entertainment programs are very important factor; training is avital factors in entertainment and need more care; matching guest need is mandatory; security and safety need more care; entertainment programs need more variety; Results that guest care need improvement. These results agree with Heidbrink, (2019). Concerning the impact of satisfaction with entertainment services the result showed that: In the first rank level is the level of guest satisfaction with entertaining services is affected by level of safety and comfort by a percentage. Followed by the level of guest satisfaction with entertainment services generates overall satisfaction and retention. Results indicate that safety first; the impact of entertainment programs on guest satisfaction; entertainment programs affect the guest expectation to repurchase; guest satisfaction with its entertainment services affect guest return again; satisfaction with its entertainment services affect guest recommend the hotel to others. These agreed with Luo and Lam, (2017).

\section{RECOMMENDATIONS}

Referring to the previous conclusion the study recommends the following to the entertainment programs presented in the floating hotels to improve its impact on guest satisfaction:

1. Hygiene and safety should be the first priorities of the entertainment programs.

2. The guest satisfaction must be among the topics that offer interest in the floating hotels, as increasing guest satisfaction increases the frequency of hotel profit.

3. Floating hotels should pay attention to evaluating the entertainment programs.

4. Floating hotels must develop a plan for entertainment team to increase and improve their performance.

5. Taking more care about training because guest satisfaction depends on the entertainment services quality.

6. Floating hotels should increase entertainment programs and introduce new activities frequency.

7. More attention should be paid to the aspect of entertainment inside hotels, through colleges and institutes of hotels, and a proposal to 
include the entertainment programs. Establishing schools and institutes to teach animation and provide them with multiple languages are recommended.

8. Identify the factors and elements that would increase guest satisfaction through entertainment programs.

9. More care regarding protective fees for security and safety to prevent problems that may be caused by entertainment programs.

10. Confirm cooperation and harmony among the employees of entertainment during the entertainment programs.

\section{REFERENCES}

Akhoondnejad, A, (2018), Loyalty Formation Process of Tourists in Sporting Event: The Case of Turkmen Horse Races. Journal of Hospitality and Tourism Management, 34, PP. 48-57, https:// doi.org /10.1 016 /j. jhtm.2017.11.006.

Al Hashemi, A; Noori, S; \& Abas, N, (2018), Recreation and entertainment The concept of sports physical activity recreational. , Available from: https://www researchgate.net/publication /329281480 _Recreation_and_entertainment", [Accessed on 23 - 09- 2019].

Allen, L. (2013) The Relationship Between Mural's Personality Needs and A Leisure Interests; New York, USA. Journal of leisure, Research,14, (1). PP. 123-142.

Antchak, V, (2017), Portfolio of Major Events in Auckland: Characteristics, Perspectives and Issues. Journal of Policy Research in Tourism, Leisure and Events, 9 (3), PP. 280-297.

Auh, S; and Johnson, D. (2005), "Compatibility Effects in Evaluations of Satisfaction and Loyalty", Journal of Economic Psychology, 26, pp. $35-58$.

Chen, K \& Sun, T, (2019), Survey and Research of Tourists' Satisfaction in Regional Tourism Demonstration Zone Based on IPA. Analysis Taking Jizhou District of Tianjin as an Example. 4th International Conference on Economy, Judicature, Administration and Humanitarian Projects (JAHP 2019). Atlantis Press. Advances in Economics, Business and Management Research, 94.PP. 561-569.

Chang, W., \& Taylor, A. (2016). The Effectiveness of Customer Participation in New Product Development: A Meta-Analysis. Journal of Marketing, 80(1), PP. 47-64. 
Davoud, B; \& Hamed, G. (2012), "E-Tourism and Customer Satisfaction Factors", International Journal of Advances in Management, 1. PP. 35-40. Available from: "http://www.ij-ams.org", [Accessed on 17 11- 2019].

De Klerk, I, (2012), The Impact of Entertainment on the Tourism SectorCase Study: Agency Remarc Greece. Unpublished Research, Central Ostrobothnia University of Applied Sciences, Unit for Technology and Business.

Egyptian Hotel Association (EHA), (2019). Egyptian Hotel Association: The Guide. Available from: "http://www.egyptianhotels.org /Default aspx", [Accessed on 06 - 03- 2020].

Ganiyu, R., Uche, I., \& Elizabeth, A. (2012). Is Customer Satisfaction an Indicator of Customer Loyalty? Australian Journal of Business and Management Research, 2, (70), pp: 14-28.335.

Hair, J., Black, W., Babin, B. and Anderson, R. (2010). "Multivariate data analysis". 7th Edition. New Jersey: Pearson Prentice Hall.

Heidbrink, I, (2019), Science vs. Entertainment - New Trends in Antarctic Tourism and needs for revised governance Polarforschung, 88 (2), PP. 89 - 97.

Hill, N; Roche, G. and Allen, R, (2007), Customer Satisfaction: The Customer Experience through the Customer's Eyes. London: Cogent Publishing.

Joel, E; and Carmina, F, (2008), Consumer Satisfaction, a key Factor of Consumer Loyalty and Buying Intention of a Product Developing Organization for Food Product, Emerald Group Publishing Limited 0007-070XDOI 10.1108/00070700810900585, British Food Journal, 110, (9), 2008, pp. 865-881. Available from: www. emeraldinsight.com/0007-070X.htm", [Accessed on 15 - 10- 2019].

John, B, (2011), Organizational Behavior. John Wiley \& Sons. pp. 32-42.

Lewin, E. (2009), "Business Customers' Satisfaction: what Happens when Suppliers Downsize?” Ind. Mark, Manag, 38, pp. 283-299.

Loi, I, (2012), Pearce, P.L. Powerful Stakeholders' Views of Entertainment in Macao's future. Journal of Business Research, 65, (1), PP. 4-12. Available from:" https://www.sciencedirect .com/science /article/ abs/pii/S014829631100244X? via\%3Dihub", [Accessed on 22 - 092019]. 
Lkhamtseden, B. \& Altanchimeg, Z. (2017). "Dimensions of Hotel Service Quality in Mongolia", The International Journal of Social Sciences. 5, (2), pp: 141- 156.

Luo, M \&Lam, F, (2017), Entertainment Tourism; Routledge: Abingdon, UK.

Luo, M; Lam, F; Li, X; Shen, H, (2016), Corporate Social Responsibility in Macau Gambling Industry. J. Qual. Assur. Hosp. Tour. 2016, 17, PP. 237-256.

Maahs, J \& Pratt, T, (2017) "I Hate These Little Turds!": Science, Entertainment, and the Enduring Popularity of Scared Straight Programs, Deviant Behavior, 38, (1), PP. 47-60, DOI: 10.1080/016 3962 5.2016.1190619 To link to this article: http ://dx.doi.org/10.1080/01639625.2016.1190619

Marques, D; Guijarro, M \& Carrilero, A, (2016). The Use of CustomerCentric Philosophy in Hotels to Improve Customer Loyalty; Journal of Business \& Industrial Marketing 31/3 (2016), PP. 339-348. (C) Emerald Group Publishing Limited [ISSN 0885-8624]. [DOI 10.1108/JBIM-05-2013-0110].

Mkono, M \& Holder, A, (2019), The future of animals in tourism recreation: Social media as spaces of collective moral reflexivity. Tourism Management Perspectives 29, PP. 1-8. DOI: 10.1016/j.tmp.2018.10.002.

Moital1, M, (2019). The Impacts of Sports Events at Tourist Destination Level. Motricidade, 15, (2), pp. 1-5. Available from:" http: //dx.doi.org/10.6063/motricidade.18360", [Accessed on 23 - 092019].

Pallant, J. (2007). "A Step by Step Guide to Data Analysis Using SPSS": Survival Manual. 3rd Edition. England, Open University Press: McGraw-Hill Education.

Petler, M; Shih, K; Jason C, Chen, H (2016), A Comparison of the Service Quality of Fast Food Chain Franchises, International Journal of Services and Standards, 3(2), PP. 222-238.

Philip, K. \&Armstrong. G, (2014). Principles of Marketing Global Edition, 15th Edition Pearson Education Limited, Harlow, England

Pratt, W; Babin, B; Carr, J; and Griffin, M, (2007), Business Research Methods, 8th ed. South-Western Cengage Learning, Canada. 
Rechner (March 11, 2010). "Letter to the Editor: Outdoor Recreation Stimulates the Economy". Washington Post, Available from: https://www.washingtontimes.com/news/2010/mar/11/outdoorrecreation-stimulates-the-economy/", [Accessed on 21 - 09-2019].

Ryan, J. (1999), "Stop the Press", Business Journal, 2 (12), pp. 196-209.

Shujat, S; Ameer, F; \&Cheema, F, (2011), Effects of Recreational and Entertainment Activities on Employees Job Satisfaction: A Case Study. 7 (1), PP. 11-18.

Syaqirah, N \& Faizurrahman, P (2014), Managing Customer Retention of Hotel Industry in Malaysia, Procedia - Social and Behavioral Sciences 130, PP. 379 - 389.

Timpe, J, (2017), Nazi-Organized Recreation and Entertainment in the Third Reich. London: Palgrave Macmillan, Available from: https://link.springer.com/content/pdf/bfm\%3A978-1-137-531933\%2F1.pdf", [Accessed on 19 - 05- 2020].

Tong, W, (2015), Analyzing the Relationship between Customer Satisfaction and Customer Loyalty, Case: Ritz-Carlton Guangzhou. Bachelor's thesis of the Degree Programmed in Business Management Bachelor Degree of Business Administration, TORNIO 2015, Available from: https://www. theseus.fi/bitstre am/handle /10024/87 964/THESIS.pdf? sequence=1", [Accessed on 23 - 09- 2019].

$\mathrm{Xu}, \mathrm{B}$, (2010) Perception of tourism products. Tourism Management 31 (2010), PP. 607-610.

Türk, S; Jakob, E; Krämer, A; \& Roth, R, (2004), Outdoor Recreation Activities in Nature Protection Areas - situation in Germany, Working Papers of the Finnish Forest Research Institute 2, Available from: "http://www.metla.fi/julkaisut/ workingpapers/ 2004/mwp002.htm", [Accessed on 20 - 09- 2019].

Weiermair, K \& Mathies C, (2007), The Tourism and Leisure Industry, Shaping the Future, Binghamton, Haworth Press. 